\title{
DESIGN, OPTIMIZATION AND EVALUATION OF IBUPROFEN FAST DISSOLVING TABLETS EMPLOYING STARCH PHTHALATE-A NOVEL SUPERDISINTEGRANT
}

\author{
R. SANTOSH KUMAR ${ }^{1 *}$, KUMARI ANNU' ${ }^{2}$, B. KUSUMA LATHA ${ }^{3}$, T. MALLIKA ${ }^{4}$ \\ 1,2,3GITAM Institute of Pharmacy, GITAM (Deemed To Be University), Rushikonda, Visakhapatnam, A. P. 530045, India, ${ }^{4}$ SrinivasaRao \\ College of Pharmacy, P. M Palem, Visakhapatnam, A. P. 530045, India \\ Email: drsantoshrada@gmail.com \\ Received: 15 May 2019, Revised and Accepted: 17 Jul 2019
}

\begin{abstract}
Objective: The objective of the present research was to prepare starch phthalate (a novel super disintegrant) and to optimize and formulate ibuprofen fast dissolving tablets employing $2^{3}$ factorial design using starch phthalate as super disintegrant.

Methods: Drug excipient compatibility studies like Fourier-transform infrared spectroscopy (FTIR) and thin-layer chromatography (TLC) studies were carried out to check the drug interaction between ibuprofen and starch phthalate. Direct compression method was used for tablet preparation. Prepared tablets were then evaluated for hardness, friability, drug content, disintegration time, water absorption and wetting time, in vitro dissolution studies. Response surface plots and contour plots were also plotted to know the main effects and interaction effects of independent variables (starch phthalate (A), croscarmellose sodium (B) and crospovidone (C)) on dependent variables (disintegration time and drug dissolution efficiency in 1 minute) and stability studies were also done.
\end{abstract}

Results: Tablets of all formulations were of good quality concerning drug content (100 $\pm 5 \%$ ), hardness (3-6 kg/cm2), and friability (less than $0.16 \%$ ). In all formulations, formulation F5 found to be optimized formulation with least disintegration time $20 \pm 0.28$ seconds, less wetting time $09 \pm 0.12$ seconds and enhanced dissolution rate in one minute, i.e., $91.95 \pm 0.22$ as compared to other formulation.

Conclusion: From the research, it was concluded that on combination with crospovidone, starch phthalate enhanced the dissolution efficiency of the drug. Hence, starch phthalate can be used as a novel disintegrant in the manufacturing of fast dissolving tablets.

Keywords: Fast dissolving, Paediatrics, Geriatric, Superdisintegrant, Starch phthalate, Ibuprofen

(C) 2019 The Authors. Published by Innovare Academic Sciences Pvt Ltd. This is an open-access article under the CC BY license (http://creativecommons.org/licenses/by/4.0/) DOI: http://dx.doi.org/10.22159/ijcpr.2019v11i5.35702

\section{INTRODUCTION}

Fast dissolving tablets are new emerged solid dosage forms over conventional tablets having advantages of both solid and liquid dosage systems. It offers convenience in tablet manufacturing, more accurate dosing than the liquid dosage forms [1]. These tablets dissolve fast as it comes in contact with saliva and hence providing the ease of administration which results in patient's compliance for pediatrics, geriatrics, dysphasic, psychic, and bed-ridden, unconscious population [2, 3]. To formulate a fast-dissolving tablet with sufficient hardness that can withstand the pressure handling during transport with the ability to disintegrate quickly as soon it comes in contact with saliva is a challenge [4]. The direct compression method is most preferred method for the preparation of mouth dissolving tablets as it does not involve heat, no requirement of water, less number of processing steps, low cost and thus it is suitable for heat-sensitive drugs [5]. In the direct compression method, super disintegrants were added to achieve quick disintegration with enhanced dissolution (within $5 \mathrm{~min}$ ). Super-disintegrants are the agents which help in rapid disintegration of tablets when they used in low concentration [6].

In market many superdisintegrants are available and still, there is research going on to find the novel super disintegrant with all the characteristics of super disintegrant for the fast-dissolving tablets. The objective of this present research was the preparation and evaluation of ibuprofen fast dissolving tablets employing starch phthalate as super disintegrant. Starch phthalate was prepared by esterification process by using potato starch and phthalic anhydride. By using $2^{3}$ factorial designs, fast dissolving tablets of ibuprofen were optimized prepared by employing starch phthalate as super disintegrant. Stability studies are conducted to find out the stability of optimized formulation using the novel super disintegrant.

\section{MATERIALS AND METHODS}

\section{Materials}

Ibuprofen, crospovidone, crosscarmellose sodium, starch and potato starch were purchased from Yarrow chemicals, Mumbai. Phthalic anhydride, dimethyl sulphoxide, acetone and isopropanol were obtained from Finar chemicals Ltd, Ahmedabad. Ethanol was bought from Changshu yangyun chemicals, china. Microcrystalline cellulose was procured from Qualigens fine chemicals, Mumbai. Magnesium stearate and Talc was purchased from Molychem, Mumbai.

\section{Preparation of a novel super disintegrant starch phthalate}

Initially 3 parts of phthalic anhydride were dissolved in 2 parts of dimethyl sulphoxide (DMSO). Then, $\mathrm{pH}$ of the solution was adjusted to $\mathrm{pH} 3.5$ using $10 \mathrm{M}$ sodium hydroxide $(\mathrm{NaOH})$ and finally made up to $50 \mathrm{ml}$. To this 5 parts of potato starch was added and conditioned for $16 \mathrm{~h}$. After conditioning the dispersion was kept it in an oven at $60^{\circ} \mathrm{C}$ for one hour. Then, the product was mixed with acetone for 15 min and then washed with isopropanol to remove any unwanted phthalic anhydride if present. After washing the resultant product (starch phthalate) was kept in an oven at $60^{\circ} \mathrm{C}$ until it gets dried. The product obtained was ground and sieved (\#120).

\section{Characterization of starch phthalate}

The starch phthalate prepared was evaluated for the following

\section{Solubility}

The solubility of starch phthalate was tested in water, an aqueous buffer of $\mathrm{pH} 1.2,4.5,7.4$ and organic solvents like petroleum ether, alcohol, acetone, dichloromethane, chloroform.

pH

By $\mathrm{pH}$ meter, $\mathrm{pH}$ of $1 \% \mathrm{w} / \mathrm{v}$ slurry was checked. 


\section{Viscosity}

The viscosity of $1 \%$ dispersion in water was measured using Ostwald viscometer.

\section{Melting point}

The melting point was checked by melting point apparatus.

\section{Swelling index}

Starch phthalate $(200 \mathrm{mg})$ was added to two different graduated test tubes containing $10 \mathrm{ml}$ of water and light liquid paraffin and mixed. In the tubes, the dispersion was allowed to stand for $24 \mathrm{~h}$. The sediment volume in the tubes was noted after $24 \mathrm{~h}$. The swelling index of the material was determined as follows [7].

$S . I=\frac{\text { Volume of sediment in water }- \text { Volume of sediment in light liquid paraffin }}{\text { Volume of sediment in light liquid paraffin }} \times 100$

\section{Test for gelling property}

The gelling property of the starch and starch phthalate was evaluated by heating $7 \% \mathrm{w} / \mathrm{v}$ dispersion of each, in distilled water at $1000{ }^{\circ} \mathrm{C}$ for $30 \mathrm{~min}$

\section{Particle size}

By optical microscopy, particle size was determined.

\section{Density}

By using benzene as a liquid, the density $(\mathrm{g} / \mathrm{cc}$ ) was measured by liquid displacement process.

\section{Bulk density}

For calculation of loose bulk density (LBD) and tapped bulk density (TBD) in $50 \mathrm{ml}$ measuring cylinder accurately weighed the amount of samples was transferred and tapped 50 times on a plane surface. Tapped volume of packing was recorded. LBD and TBD measured by the following formula [8].

$$
\begin{gathered}
\mathrm{LBD}=\frac{\text { Mass of powder }}{\text { Volume of packing }} \\
\mathrm{TBD}=\frac{\text { Mass of powder }}{\text { Tapped volume of packing }}
\end{gathered}
$$

\section{Percentage compressibility index}

Carr's compressibility index calculated by the given following formula to check the Percentage compressibility of powder mix.

$$
\% \text { Carr's Index }=\frac{(\mathrm{TBD}-\mathrm{LBD})}{\mathrm{TBD}} \times 100
$$

Where TBD = Tapped bulk density; LBD = Loose bulk density .

\section{Angle of repose}

The angle of repose is determined to check the frictional forces in loose powder or granules and calculated by the given equation [9]

$$
\tan \theta=\frac{h}{r}
$$

$$
\theta=\tan ^{-1} \frac{\mathrm{h}}{\mathrm{r}}
$$

Where $\theta=$ angle of repose; $h=$ height of pile; $r$ = radius of pile.

\section{Fourier transform infrared (FTIR) spectroscopy}

Fourier transform infrared spectroscopy (FTIR) spectra of starch phthalate were recorded on samples prepared in potassium bromide $(\mathrm{KBr})$ disks using a BRUKER FT-IR, (Tokyo, Japan). Potassium bromide $(\mathrm{KBr})$ disks of samples were prepared at 6-8 tons hydrostatic press and analyzed sample between scanning range 500 to $4000 \mathrm{~cm}-1$.

\section{Drug-Excipients compatibility studies}

The compatibility of starch phthalate with the selected drug (ibuprofen) was evaluated in Fourier transform infrared spectroscopy (FTIR) and thin-layer chromatography (TLC) studies.

\section{Fourier transform infrared (FTIR) spectroscopy}

Fourier transforms infrared spectroscopy (FTIR) spectra of ibuprofen and their mixtures (1: 1) with starch phthalate were recorded by IR Spectrophotometer (Perkin Elmer model) using Potassium bromide $(\mathrm{KBr})$ disc as a reference.

\section{Thin-layer chromatography (TLC) study}

Stationary Phase: Silica gel H (pre-coated TLC plates).

Mobile Phase: n-Hexane: Ethyl Acetate: Glacial Acetic Acid (75:25:5)

\section{Procedure}

The mobile phase was prepared and taken in a thin layer chromatography (TLC) chamber. The chamber was allowed to saturate with solvent vapor for $24 \mathrm{~h}$. Standard (pure drug) and test (drug-starch phthalate mixtures) sample were spotted on activated silica plates using narrow capillary tubes. The spotted plates were kept in the thin layer chromatography (TLC) chamber and allowed to run the mobile phase. The plates were dried and kept in Iodine chamber to develop the spots. The retardation factor (Rf) values of standard and test samples were determined by the following formula.

Retardation factor $(\mathrm{Rf})=$ Distance travelled by sample/Distance travelled by solvent front.

\section{Preparation of fast dissolving tablets of ibuprofen}

By direct compression method fast dissolving tablets of ibuprofen was prepared by employing $2^{3}$ factorial designs in which super disintegrants i.e., starch phthalate(A), croscarmellose sodium (B), crospovidone (C) are selected as three independent variables and dissolution efficiency in 1 minute as the dependent variable. The composition of different formulation of ibuprofen fast dissolving tablets is given in table no 1 . For particle size uniformity each ingredient was flown through \#100 mesh sized screen before mixing. Starch phthalate, crospovidone, microcrystalline cellulose, croscarmellose sodium, starch were accurately weighed mixed using mortar and pestle, and then ibuprofen was added. At last to the

\begin{tabular}{|c|c|c|c|c|c|c|c|c|}
\hline Ingredients (mg/tablet) & F1 & F2 & F3 & F4 & F5 & F6 & F7 & F8 \\
\hline Ibuprofen & 200 & 200 & 200 & 200 & 200 & 200 & 200 & 200 \\
\hline Starch phthalate & 25 & 50 & 25 & 50 & 25 & 50 & 25 & 50 \\
\hline Croscarmellose sodium & -- & --- & 25 & 25 & -- & -- & 25 & 25 \\
\hline Crospovidone & --- & --- & --- & -- & 25 & 25 & 25 & 25 \\
\hline Starch & 50 & 50 & 50 & 50 & 50 & 50 & 50 & 50 \\
\hline Micro crystalline cellulose & 205 & 180 & 180 & 155 & 180 & 155 & 155 & 155 \\
\hline Talc & 10 & 10 & 10 & 10 & 10 & 10 & 10 & 10 \\
\hline Magnesium Stearate & 10 & 10 & 10 & 10 & 10 & 10 & 10 & 10 \\
\hline Total & 500 & 500 & 500 & 500 & 500 & 500 & 500 & 500 \\
\hline
\end{tabular}
powder mix talc and magnesium stearate were added. Finally, the mixed blend was compressed by using eight-station rotor press Karnawathi Machineries Pvt, Ltd., Ahmedabad, India).

Table 1: Formulae of ibuprofen fast dissolving tablets employing starch phthalate prepared by direct compression method 


\section{Evaluation of ibuprofen fast dissolving tablets}

\section{Hardness test}

By using Monsanto hardness tester hardness of tablets was determined and unit for the hardness is $\mathrm{kg} / \mathrm{cm}^{2}[10]$.

\section{Uniformity of weight}

Twenty tablets were selected for the weight variation test. It is the individual variation of a tablet weight from the average weight of 20 tablets [11].

\section{Friability}

By using Roche friabilator, friability of all tablets was determined. At $25 \mathrm{rpm}$, tablets were rotated for $4 \mathrm{~min}$ or up to 100 revolutions. Tablets were weighed again after the removal of fine dust from the tablet surface, and weight loss percentage was calculated by the given formula [12]

$$
=\frac{100 \times W \text { (initial) }-W(\text { final })}{W \text { (initial) }}
$$

\section{Drug content uniformity}

For content uniformity, ten tablets were weighed and powdered a quantity of powder equivalent to $10 \mathrm{mg}$ of ibuprofen, was extracted into $\mathrm{pH} 7.2$ phosphate buffer and filtered. The ibuprofen content was determined by measuring the absorbance using the spectrophotometric method at $221 \mathrm{~nm}$ after appropriate dilution with $\mathrm{pH} 7.2$ phosphate buffer. The drug content was measured as an average of three determinations [13].

\section{Wetting time and water absorption ratio}

In a Petri dish of $10 \mathrm{~cm}$ diameter, five pieces of circular tissue paper were placed. Ten $\mathrm{ml}$ of water containing a water-soluble dye (amaranth) was added to the Petri dish. Carefully keep the one tablet in between the tissue paper and the time taken to reach the upper surface of the tablet was noted as wetting time.

\section{Water absorption ratio}

Fold the tissue paper twice as per the diameter of the Petri dish and $6 \mathrm{ml}$ of water was added to the Petri dish. A tablet was kept on the tissue paper and allowed to wet completely and weighed the wetted tablet. Water absorption ratio is calculated by using the given Equation [14].

$$
R=\frac{100\left(W_{\mathrm{d}}-W_{\mathrm{e}}\right)}{W_{e}}
$$

Where,

\section{$\mathrm{W}_{\mathrm{d}}=$ Tablet weight after water absorption. \\ $\mathrm{W}_{\mathrm{e}}=$ Tablet weight before water absorption.}

\section{In-vitro disintegration time}

Disintegration time for FDTs was determined using USP disintegration apparatus $\mathrm{pH} 7.2$ phosphate buffer. The volume of medium was $900 \mathrm{ml}$ and the temperature was $37 \pm 0.2^{\circ} \mathrm{C}$. The time in seconds taken for complete disintegration of the tablet with no palatable mass remaining in the apparatus was determined [15].

\section{In-vitro dissolution studies}

The in vitro dissolution rate study of ibuprofen fast dissolving tablets were performed using 8 stage dissolution test apparatus (Electrolab TDT-08L) fitted with paddles ( $50 \mathrm{rpm}$ ) at $37 \pm 0.5^{\circ} \mathrm{C}$, using $\mathrm{pH} 7.2$ phosphate buffer $(900 \mathrm{ml})$ as a dissolution media. At the predetermined time intervals, $5 \mathrm{ml}$ samples were withdrawn, filtered through $0.45 \mu$ membrane filter, diluted and assayed at 221 nm using an Analytical technology T360 UV/Visible Double beam spectrophotometer. All the dissolution experiments were conducted in triplicate $(\mathrm{n}=3)$.

\section{Response surface plot study}

Optimization of the ibuprofen fast dissolving tablets was done using $2^{3}$ factorial designs in which 3 factors each at two levels were evaluated. To evaluate the individual and combined effects of starch phthalate (factor A), croscarmellose sodium (factor B) and crospovidone (factor C), response surface plot method was conducted.

A polynomial regression algorithm was used to rotate the independent variables to the response variables. The general firstorder model and equation they could be constructed from $2^{\mathrm{n}}$ experimental design is indicated in the following equation.

$$
Y=\beta_{0}+\beta_{1} A+\beta_{2} B+\beta_{2} C+\beta_{1} \beta_{2} A B+\beta_{1} \beta_{3} A C+\beta_{2} \beta_{3} B C+\beta_{1} \beta_{2} \beta_{3} A B C
$$

where $y$ is the measured response, $\beta_{0}$ is the arithmetic mean response of 1 min, $\beta_{1}, \beta_{2}, \beta_{3}, \beta_{1} \beta_{2}, \beta_{1} \beta_{3}, \beta_{2} \beta_{3}, \beta_{1} \beta_{2} \beta_{3}$ are coefficients for the corresponding factors and $\mathrm{A}, \mathrm{B}, \mathrm{C}, \mathrm{AB}, \mathrm{AC}, \mathrm{BC}$, and $\mathrm{ABC}$ are the percentages of starch phthalate, croscarmellose sodium and crospovidone and interaction terms respectively. The coefficients were calculated accordingly to the general formula given in equation.

$$
\mathrm{B}=\Sigma \mathrm{XY} / 2^{\mathrm{n}}
$$

Where $\beta$ is coefficient, $X$ is the corresponding variable $(A, B, C)$ and $Y$ is the response value (dissolution efficiency in 1 minute), $n$ is the level. The two levels of three factors employed in the experimental design are indicated in table 2 and transformed design for analysis of responses of ibuprofen fast dissolving tablets is shown in table 3.

Table 2: Levels of the three factors used in experimental design

\begin{tabular}{llll}
\hline S. No. & Factors/Ingredients & Code & Level L1 \\
\hline 1 & Starch phthalate & A & 5 \\
2 & Croscarmellose sodium & B & 10 \\
3 & Crospovidone & C & 5 \\
\hline
\end{tabular}

Table 3: Transformed design for analysis of response of ibuprofen fast dissolving tablets

\begin{tabular}{lllll}
\hline S. No. & Formula code & A (\%) & B (\%) \\
\hline 1 & F1 & 5 & 0 \\
2 & F2 & 10 & 0 & C (\%) \\
3 & F3 & 5 & 5 & 0 \\
4 & F4 & 10 & 5 & 0 \\
5 & F5 & 5 & 0 & 0 \\
7 & F6 & 5 & 5 & 5 \\
8 & F7 & 5 & 5 & 5 \\
\hline
\end{tabular}




\section{Stability studies}

As per ICH stability guidelines, stability studies were performed to check the changes in the quality of a drug substance or drug product with time with respect to various environmental factors like temperature, humidity and light stability. Stability studies of F5 formulation were carried out. The tablets were packed in screwcapped HDPE bottles and were stored at $40{ }^{\circ} \mathrm{C} \pm 2{ }^{\circ} \mathrm{C}$ and $75 \% \mathrm{RH}$ for
6 mo. After storage for $6 \mathrm{mo}$, the products were tested for drug content and drug release rate.

\section{RESULTS AND DISCUSSION}

The starch phthalate prepared was found to be fine, smooth, freeflowing amorphous powder. The physical and micropolitics properties of the starch phthalate are summarized in table 4.

Table 4: Physical and micropolitics properties of the starch phthalate prepared

\begin{tabular}{ll}
\hline Parameters & Observation \\
\hline Solubility & Insoluble in all aqueous and organic solvents tested \\
pH(1\% w/v aqueous dispersion) & $2.88 \%$ \\
Melting Point & Charred at $325^{\circ} \mathrm{C}$ \\
Viscosity(1\% w/v aqueous dispersion) & $1.08 \mathrm{cps}$ \\
Swelling index & $65 \%$ \\
Gelling property & No gelling and the swollen particles of starch phthalate separated from water. Whereas in the case of \\
& starch, it was gelatinized and formed gel. \\
Moisture absorption & $4.4 \%$ \\
Particle Size & $158 \mu \mathrm{m}(80 / 120$ mesh $)$ \\
Density & $0.584 \mathrm{~g} / \mathrm{cc}$ \\
Bulk Density & $0.555 \mathrm{~g} / \mathrm{cc}$ \\
Angle of Repose & $27.47^{\circ}$ \\
Compressibility Index & $14.23 \%$ \\
\hline
\end{tabular}

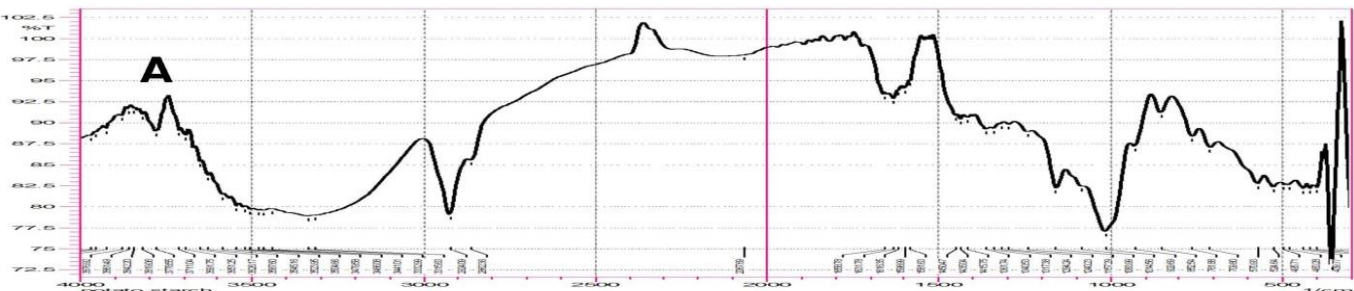

A) FTIR Spectra of Potato Starch

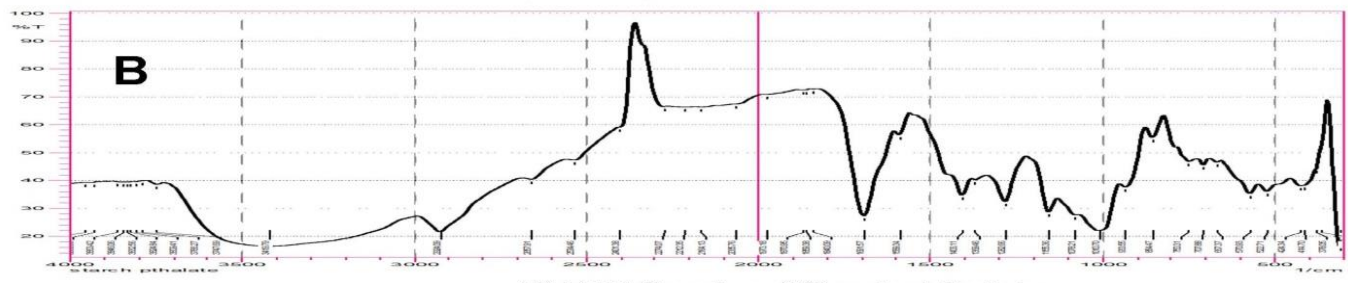

B) FTIR Spectra of Starch phthalate

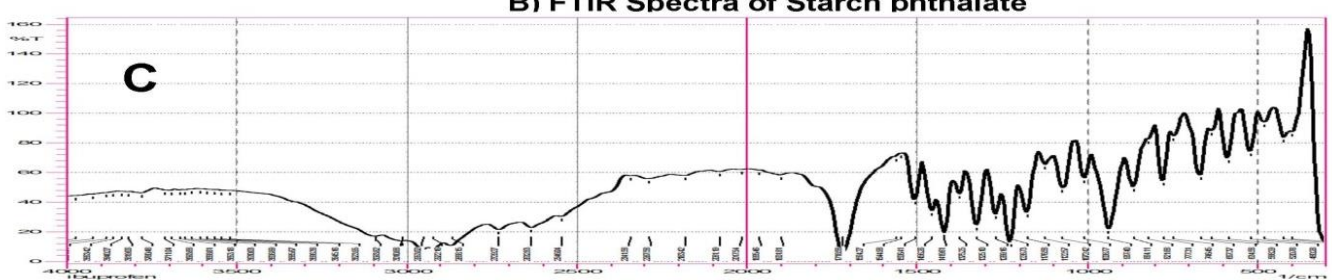

C) FTIR Samples of Ibuprofen Pure drug

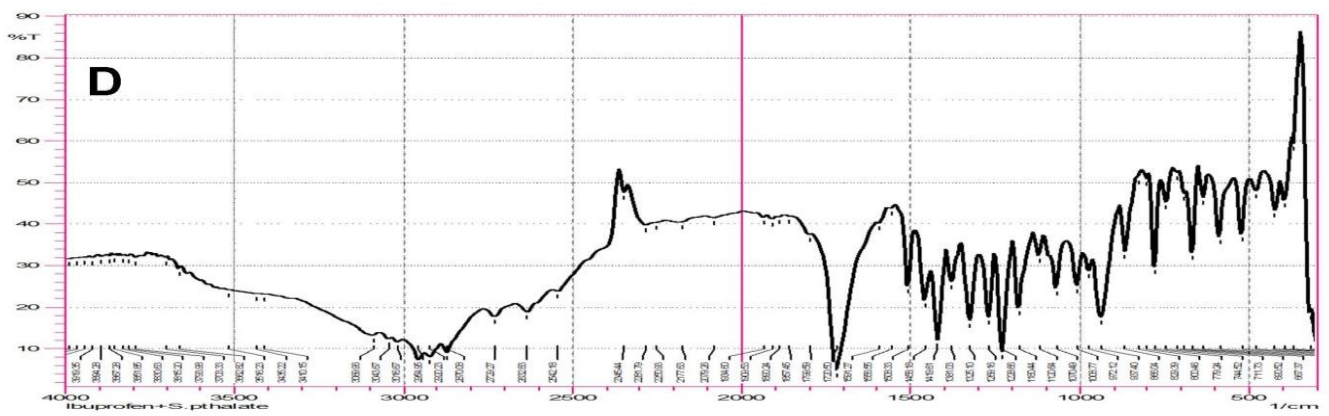

D) FTIR Spectra of Ibuprofen with Starch Phthalate

Fig. 1: Fourier transform infrared spectra (FTIR) of (A Potato starch) (B starch phthalate) (C Ibuprofen) (D Ibuprofen and starch phthalate) 
The Fourier-transform infrared spectroscopy (FTIR) spectrum of starch and starch phthalate is shown in fig. 1(A and B). The presence of peaks of absorption at $1691.57 \mathrm{~cm}^{-1}$ characteristic peaks of ester, so from Fourier-transform infrared spectroscopy (FTIR) studies it was concluded that starch phthalate (ester) was formed when starch was allowed to react with phthalic anhydride. The disappearance of pink colour in the ester test confirmed the presence of ester, i.e., starch phthalate. As the starch phthalate was amorphous, smooth, freeflowing powder and it had got all the characteristic of super disintegrants it was concluded that starch phthalate can be used as novel super disintegrant in the formulation of fast dissolving tablets.

The compatibility of starch phthalate with the selected drug (ibuprofen) was evaluated by Fourier-transform infrared spectroscopy (FTIR) and thin-layer chromatography (TLC) studies.

The FTIR spectra of ibuprofen and ibuprofen-starch phthalate are shown in fig. $1(\mathrm{C}$ and $\mathrm{D}$ respectively). The characteristic Fouriertransform infrared spectroscopy (FTIR) band of Ibuprofen at $1718.58 \mathrm{~cm}^{-1}(-\mathrm{COOH})$ was observed in the Fourier-transform infrared spectroscopy (FTIR) spectra of both ibuprofen and ibuprofen-starch phthalate. These Fourier-transform infrared spectroscopy (FTIR) spectral observations also indicated no interaction between starch phthalate and drug selected.

In thin-layer chromatography (TLC) plate of ibuprofen and ibuprofen-starch, single spots were observed in the case of pure drug as well as their mixtures with starch phthalate. The close agreement of the retardation factor (Rf) values of the drug $(0.76)$ and its mixture with starch phthalate $(0.68)$ indicated no interaction between the drug and starch phthalate.

The hardness of tablets from all batches was found to be in the range of $3-6 \mathrm{~kg} / \mathrm{cm}^{2}$. All the tablets exhibited acceptable friability as weight loss on the friability test was less than $0.16 \%$ in all formulations. Drug content of all the formulation batches was found to be within $100 \pm 5 \%$ of the labeled amount.

The in-vitro disintegration time and water absorption ratio of all the formulations (F1-F8) are given in table 5. Formulation F8 containing $10 \%$ starch phthalate, $5 \%$ crospovidone and $5 \%$ croscarmellose sodium showed less wetting time i.e. $05 \pm 0.09 \mathrm{~s}$ as compared to other formulations. In vitro dissolution test was carried out in United States Pharmacopeia (USP) type II paddle apparatus and dissolution profile of formulations F1-F4 is shown in fig. 2 (A) and F5-F8 is shown in fig. 2 (B). Percent dissolved in 1 minute $\left(\mathrm{PD}_{1}\right)$ was found to be more in $\mathrm{F} 5$ formulation which consists of $5 \%$ starch phthalate, $0 \%$ croscarmellose sodium and 5\% crospovidone. The same was in the case of dissolution efficiency in 1 min ( $\left.D_{1} \%\right)$. The Percent dissolved in 1 minute $\left(\mathrm{PD}_{1)}\right.$ and dissolution efficiency in $1 \mathrm{~min}$ $\left(\mathrm{DE}_{1} \%\right)$ reveals that starch phthalate was effective at $5 \%$ starch Phthalate, $0 \%$ croscarmellose sodium and $5 \%$ crospovidone when the formulations were made by direct compression using these super disintegrants given in table 6 .

A

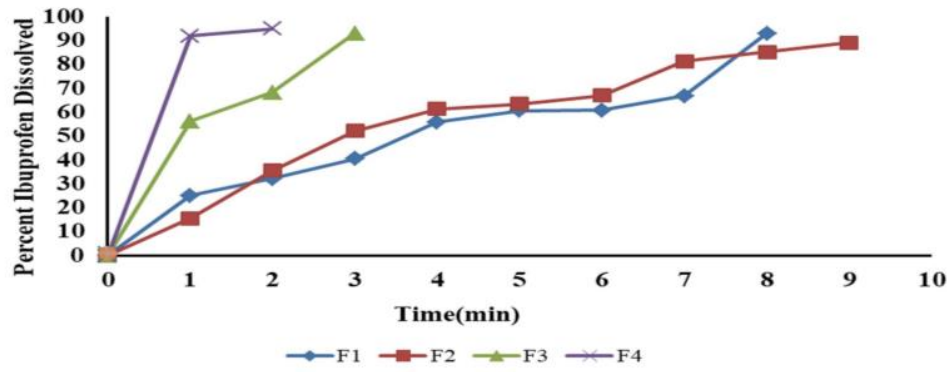

A) Dissolution Profiles of Ibuprofen Fast Dissolving Tablets (F1 - F4)

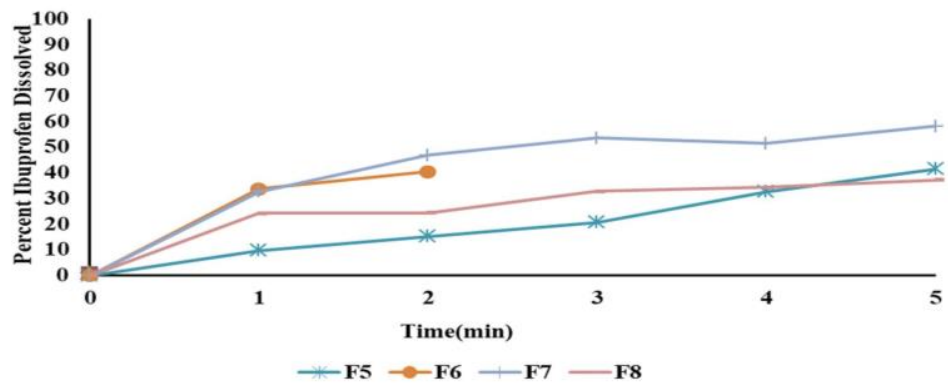

B) Dissolution Profiles of Ibuprofen Fast Dissolving Tablets (F5- F8)

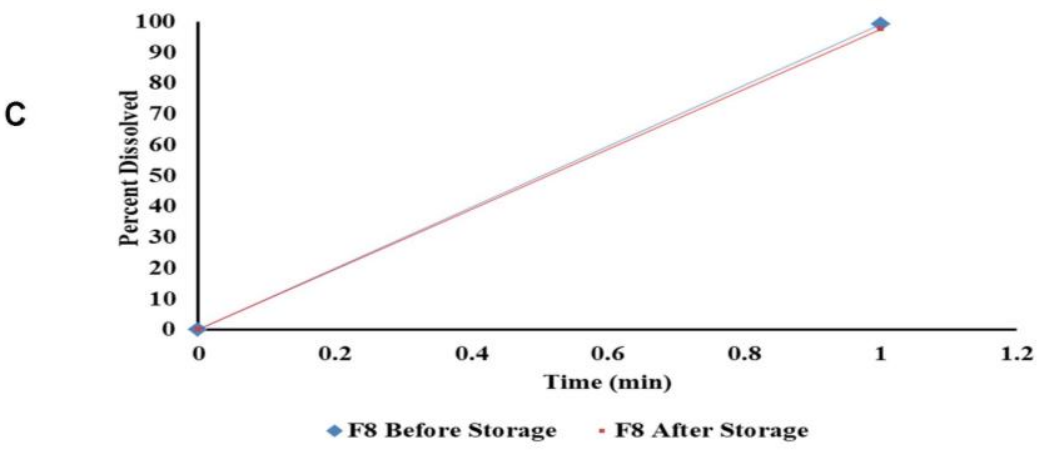

C) Dissolution Profiles of Ibuprofen Fast Dissolving Tablets Before and After 6 months During the Stability Testing.

Fig. 2: Dissolution profiles of Ibuprofen fast dissolving tablets employing starch phthalate A) of formulations F1-F4 B) of formulations F5F8 C) of formulation F5 before and after stability testing 
Table 5: Physical properties: hardness, friability, drug content of ibuprofen fast dissolving tablets prepared by direct compression method

\begin{tabular}{|c|c|c|c|c|c|c|}
\hline Formulation & $\begin{array}{l}\text { Hardness } \\
\left(\mathrm{Kg} / \mathrm{Cm}^{2}\right) \mathrm{n} \pm \mathrm{SD}\end{array}$ & $\begin{array}{l}\text { Friability } \\
\text { (\%) } n \pm S D\end{array}$ & $\begin{array}{l}\text { Drug content } \\
(\mathrm{mg} / \mathrm{tab}) \mathrm{n} \pm \mathrm{SD}\end{array}$ & $\begin{array}{l}\text { Disintegration } \\
\text { time (sec) } n \pm S D\end{array}$ & $\begin{array}{l}\text { Wetting time (sec) } \\
\mathrm{n} \pm \text { SD }\end{array}$ & $\begin{array}{l}\text { Water absorption ratio } \\
\text { (\%) } n \pm \text { SD }\end{array}$ \\
\hline F1 & $3.9 \pm 0.01$ & $0.12 \pm 0.013$ & $198 \pm 0.71$ & $45 \pm 0.24$ & $17 \pm 0.11$ & $50.0 \pm 0.15$ \\
\hline $\mathrm{F} 2$ & $3.6 \pm 0.03$ & $0.13 \pm 0.015$ & $199 \pm 0.79$ & $27 \pm 0.29$ & $16 \pm 0.15$ & $54.5 \pm 0.19$ \\
\hline F3 & $4.0 \pm 0.01$ & $0.14 \pm 0.012$ & $198 \pm 0.63$ & $24 \pm 0.15$ & $16 \pm 0.25$ & $56.3 \pm 0.11$ \\
\hline $\mathrm{F} 4$ & $3.8 \pm 0.04$ & $0.12 \pm 0.014$ & $198 \pm 0.55$ & $38 \pm 0.11$ & $22 \pm 0.07$ & $51.9 \pm 0.23$ \\
\hline F5 & $3.7 \pm 0.03$ & $0.14 \pm 0.014$ & $199 \pm 0.56$ & $20 \pm 0.28$ & $09 \pm 0.12$ & $54.7 \pm 0.25$ \\
\hline F6 & $3.9 \pm 0.01$ & $0.15 \pm 0.012$ & $198 \pm 0.18$ & $14 \pm 0.12$ & $08 \pm 0.18$ & $57.8 \pm 0.18$ \\
\hline F7 & $3.7 \pm 0.02$ & $0.14 \pm 0.014$ & $198 \pm 0.57$ & $12 \pm 0.09$ & $07 \pm 0.23$ & $60.6 \pm 0.13$ \\
\hline F8 & $4.0 \pm 0.04$ & $0.12 \pm 0.013$ & $198 \pm 0.11$ & $09 \pm 0.13$ & $05 \pm 0.09$ & $60.9 \pm 0.22$ \\
\hline
\end{tabular}

*SD Standard Deviation from mean, $\mathrm{n}=3$

Table 6: Dissolution parameters of ibuprofen fast dissolving tablets formulated employing starch phthalate

\begin{tabular}{llllllll}
\hline Parameters & F1 & F2 & F3 & F4 & F5 & F6 & F7 \\
\hline $\mathrm{PD}_{1}$ & $25.04 \pm 0.09$ & $15.55 \pm 0.11$ & $56.25 \pm 0.10$ & $91.95 \pm 0.08$ & $91.95 \pm 0.10$ & $88.04 \pm 0.07$ & $90.97 \pm 0.12$ \\
$\mathrm{DE}_{1}(\%)$ & $20 \pm 0.07$ & $10.74 \pm 0.14$ & $42.19 \pm 0.14$ & $85 \pm 0.11$ & $85.0 \pm 0.11$ & $80 \pm 0.10$ & $84.9 \pm 0.11$ \\
$\mathrm{~K}\left(\mathrm{~min}^{-1}\right)$ & $0.18 \pm 0.08$ & $0.241 \pm 0.08$ & $0.573 \pm 0.07$ & $2.97 \pm 0.13$ & $2.52 \pm 0.08$ & $0.99 \pm 0.09$ & $2.40 \pm 0.08$ \\
\hline
\end{tabular}

*SD standard deviation from mean, $\mathrm{n}=3$, PD1--percent dissolved in 1 min., DE1\%-dissolution efficiency in $1 \mathrm{~min} ., \mathrm{K} 1$ =first order rate constant
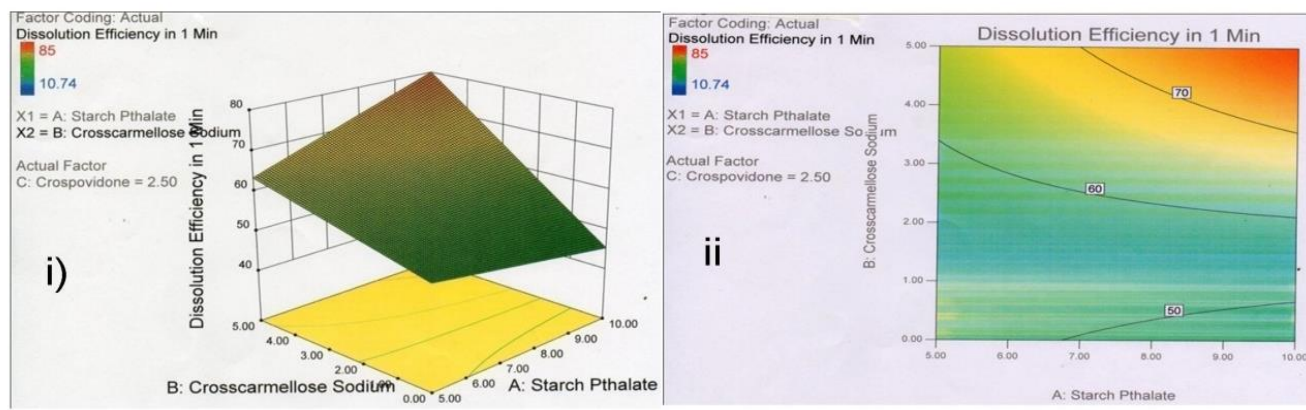

(A) Response Plot (B) Contour Plot of Ibuprofen Fast Dissolving Tablets (Effect of Starch Phthalate and

Croscarmellose Sodium on Dissolution Efficiency in $1 \mathrm{~min}$ ).
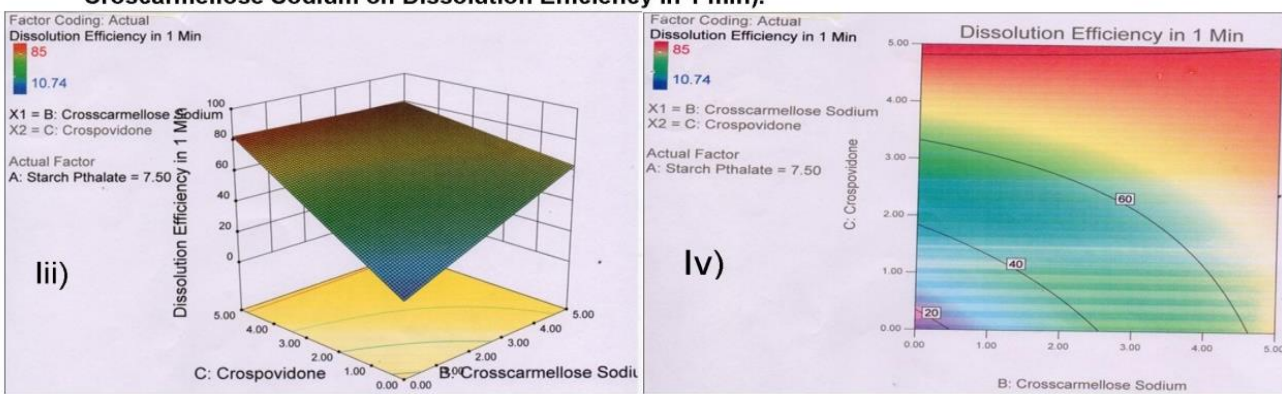

(C) Response Plot (D) Contour Plot of Ibuprofen Fast Dissolving Tablets (Effect of Croscarmellose Sodium and crospovidone on Dissolution Efficiency in $1 \mathrm{~min}$ ).
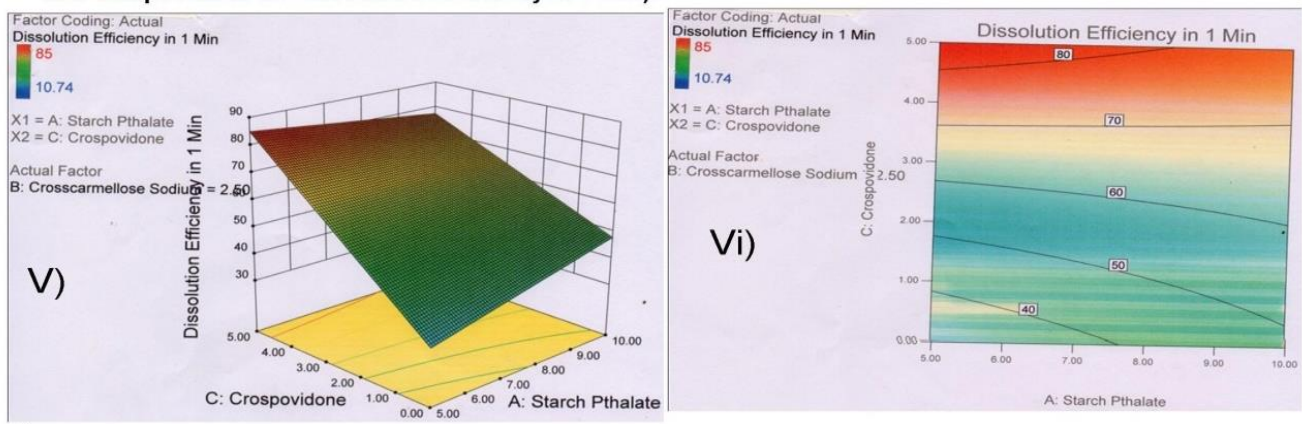

(E) Response Plot (F) Contour Plot of Ibuprofen Fast Dissolving Tablets (Effect of Starch phthalate and crospovidone on Dissolution Efficiency in $1 \mathrm{~min}$ ).

Fig. 3: Response plot and contour plot of ibuprofen fast dissolving tablets employing starch phthalate showing the effect of starch phthalate, croscarmellose sodium and crospovidone on dissolution efficiency in 1 min 
The response surface plot and the contour plot reveal that as a concentration of A (starch phthalate), B (croscarmellose sodium), C (crospovidone) increases dissolution efficiency in 1-minute increases. The effect of A (starch phthalate) and B (croscarmellose sodium) on dissolution efficiency in 1 minute are shown in fig. 3(i). The contour plots were found to be linear to a certain extent. It was determined from the contour plot fig. 3(ii) that more dissolution efficiency in $1 \mathrm{~min}$ can be obtained with A (starch phthalate) level range between 7 and 8 $\%$ and $\mathrm{B}$ (croscarmellose sodium) level range 4 to $5 \%$. The effects of $\mathrm{B}$ (croscarmellose sodium) and $C$ (crospovidone) are shown in fig. 3(iii). The contour plots were found to be almost linear indicating the linear relationship between B (croscarmellose sodium) and C (crospovidone). It was determined from the contour plot fig. 3(iv) that more dissolution efficiency in 1 minute can be obtained with B (croscarmellose sodium) level range between 4 and $5 \%$ and $\mathrm{C}$ (crospovidone) level range 4 to $5 \%$. The effects of A (starch phthalate) and $C$ (crospovidone) are shown in fig. $3(\mathrm{v})$. The contour plots were found to be linear indicating the linear relationship between A (starch phthalate) and $\mathrm{C}$ (crospovidone). It was determined from the contour plot fig. 3 (vi) more dissolution efficiency in $1 \mathrm{~min}$ can be obtained in $\mathrm{A}$ (starch phthalate) level range between 7 and $8 \%$ and $\mathrm{C}$ (crospovidone) level range between 4 to $5 \%$.

\section{CONCLUSION}

Starch phthalate is an efficient superdisintegrant for fast dissolving tablets. The disintegration and dissolution efficiency of the fast dissolving tablets of ibuprofen was good and depended on the concentration of superdisintegrant employed i.e., starch phthalate (5\%) and crospovidone (5\%). The formulated fast dissolving tablets of ibuprofen employing starch phthalate and crospovidone exhibited good dissolution efficiency in 1 min which can be used for the fast therapeutic action of ibuprofen.

Overall, Starch phthalate was found to be a superdisintegrant which enhanced the dissolution efficiency when combined with crospovidone and croscarmellose sodium, with the ibuprofen and hence it could be used in the formulation of fast dissolving tablets to provide immediate release of the contained drug within $1 \mathrm{~min}$.

\section{ACKNOWLEDGMENT}

The authors are thankful to the principal and management of GITAM Institute of Pharmacy (GITAM), Visakhapatnam and Srinivasa Rao College of Pharmacy, Visakhapatnam for providing necessary facilities to carry out this work.

\section{AUTHORS CONTRIBUTIONS}

All the author have contributed equally

\section{CONFLICT OF INTERESTS}

The authors confirm that this article content has no conflict of interest.

\section{REFERENCES}

1. Ashish Masih, Amar Kumar, Shivam Singh, Ajay Kumar Tiwari. Fast dissolving tablets: a review. Int J Curr Pharm Res 2017;9:8-18.

2. Aher Smita S, Saudagar RB, Shinde Mayuri S. Review fastdissolving tablets. Int J Curr Pharm Res 2018;9:5-12.

3. Anupam Roy. Orodispersible tablets: a review. Asian J Pharm Clin Res 2016;9:19-26.

4. Shivangi Singh, Navneet Verma. Taste masked orodispersible tablets: a highly patient complaint dosage form. Asian J Pharm Clin Res 2016;9:385-91.

5. Pratik Swarup Das, Sushma Verma, Puja Saha. Fast dissolving tablet using solid dispersion technique: a review. Int J Curr Pharm Res 2017;9:1-4.

6. Mangesh M Kumare, Rajendra P Marathe, Rajendra M Kawade Mahavir H Ghante, Giridhar R Shendarkar. Design of fast dissolving tablet of atenolol using novel co-processed super disintegrant. Asian J Pharm Clin Res 2013:6:81-5.

7. Ashish Garg, MM Gupta. Mouth dissolving tablets: a review. JDDT 2013;3:207-14.

8. Ashish Masih, Ajay Kumar Tiwari. Formulation and evaluation of fast dissolving tablets of amoxycillin trihydrate and potassium clavulanate. Int J Curr Pharm Res 2017;9:48-58.

9. Piyush Jain, RN Gupta, Sandeep Shrivastava. Formulation and evaluation of mouth dissolving tablets of omeprazole. Int J Curr Pharm Res 2016;8:48-51.

10. Shireen Begum, Syed Abdul Azeez Basha, Shazia Fatima. Formulation and in vitro evaluation of mouth dissolving tablets of amlodipine and rosuvastatin. Int J Curr Pharm Res 2015; 7:88-91.

11. Shiva Kumar Yellanki. Design and in vitro evaluation of orally disintegrating tablets of selegiline. Int J Curr Pharm Res 2015; 7:37-9.

12. Yella Sirisha, Gopala Krishna Murthy TE, Avanapu Srinivasa Rao. Effect of formulation factors on orodispersible triptan formulations-novel approach in treatment of migraine. Asian J Pharm Clin Res 2018;11:212-9.

13. Sarfaraz Mohammed, Surendra Kumar Sharma, Kalpana Kaucha, Doddayya Hiremath. Formulation and evaluation of flurbiprofen fast disintegrating tablets using natural superdisintegrants. Asian J Pharm Clin Res 2016;9:247-54.

14. Jahan Nur Rahman Hazarika, Pulak Deb. Formulation evaluation and optimization of immediate release tablet of aceclofenac by direct compression method. Int J Curr Pharm Res 2017;9:118-22.

15. Hrishav Das Purkayastha, Bipul Nath. Formulation and evaluation of oral fast disintegrating tablet of ibuprofen using two super disintegrants. Int J Curr Pharm Res 2017;9:92-5. 